\title{
Insurance and Management of Political Risk Exposure in Developed Economies and Serbia
}

Siniša Ostojić, Željka Unković*

Abstract:

The paper explores the risks, associated with government actions, which reduce the value of the company, in other words, a political risk. The purpose of this research is to determine the theoretical, institutional, regulatory management and implemented activities of political risks in different countries (the USA, the UK, France, Japan and Germany). The aim of this paper is the analysis of the characteristics of political risks, the analysis and the characteristics of the risk of the insurance policy from the standpoint of global, regional and state agencies and private insurers as well, determining the interdependence of political risks and country risks. The analysis begins by reviewing different ways of entering foreign markets (exports, foreign direct investment, contractual agreements and establishment of subsidiaries), all of which imply exposure to political risk. After that, political risk and exposure of its basic elements are defined, as well as methods that are applied in the assessment and the management of political risks. This paper concludes with an overview of political risk insurance coverage and sums insured in selected countries, and how political risk is underwritten and priced.

Keywords: political risk management, elements of political risk, national export-import banks

JEL: G; G2; G22

DOI: $10.2478 / \mathrm{v} 10033-011-0018-7$

\section{Method of entry into foreign markets}

Prior knowledge of the law, history, culture, economics and insurance of the potential foreign country partner, capital power, diplomatic and political relations and willingness to take risks are all aspects of choosing to enter a foreign market. Economic development is operationalized by transcending national boundaries (on which there is unanimity), and the foundations of globalization that bring with them many advantages and opportunities as well as threats. Since the time of Adam Smith there has been practical unanimity among economists, regardless of their ideological position on other issues, that free international trade is in the best interests of countries that trade, and in the interest of the world. The intervention of one state in favor of local companies incites companies in other countries to seek help from their governments to oppose the measures taken by the first government. All trade negotiations become a matter of politics (Friedman and Friedman, 1996, pp. 57 -70). Although called "free" international trade, it is never and nowhere operationalized in its literal sense of "free" because each state sets the rules and manners of treatment, but also takes care of its own interests first.

The method of entry into foreign markets may be in the form of exports, joint ventures and wholly owned subsidiaries. Exports can be operationalized through companies registered for export or directly through the export department, which increases not only financial benefit but risk exposure as well. The structure of exports

\footnotetext{
* Siniša Ostojić

Faculty of Economics, Subotica,

Department in Novi Sad

E-mail: sostojic@beotel.net

Željka Unković

Erste bank ad Novi Sad

E-mail: zeljkaunkovic@yahoo.com
} 


\begin{tabular}{|c|c|c|c|c|c|c|c|c|}
\hline Region / economy & & & & & & & & \\
\hline Years & '48 & 53. & '63. & '73. & '83. & '93. & '03. & '08. \\
\hline The World & 100 & 100 & 100 & 100 & 100 & 100 & 100 & 100 \\
\hline North America & 28 & 25 & 20 & 17 & 17 & 18 & 16 & 13 \\
\hline U.S. & 22 & 19 & 15 & 12 & 11 & 13 & 10 & 8 \\
\hline South and Central America & 11 & 10 & 6 & 4 & 4 & 3 & 3 & 4 \\
\hline Europe & 35 & 39 & 48 & 51 & 44 & 45 & 46 & 42 \\
\hline Germany & 1 & 5 & 9 & 12 & 9 & 10 & 10 & 9 \\
\hline United Kingdom & 2 & 2 & 3 & 4 & 5 & 5 & 4 & 3 \\
\hline Commonwealth of Independent S. & - & - & - & - & - & - & 3 & 5 \\
\hline Africa & 7 & 7 & 6 & 5 & 5 & 3 & 2 & 4 \\
\hline Middle East & 2 & 3 & 3 & 4 & 7 & 4 & 4 & 7 \\
\hline Asia & 14 & 13 & 13 & 15 & 19 & 26 & 26 & 28 \\
\hline China & 1 & 1 & 1 & 1 & 1 & 3 & 6 & 9 \\
\hline Japan & 0 & 2 & 4 & 6 & 8 & 10 & 6 & 5 \\
\hline
\end{tabular}

Source: WTO Publications, 2008, International Trade Statistics, WTO Secretariat, Geneva, pp. 10.

Table 1: World merchandise exports by selected economy, $1948-2008$

has changed substantially over the past 60 years. North America's share in world exports of $28.1 \%$ in 1948 has been superseded by Asia, which has achieved participation in the growth of world exports at $27.7 \%$ in 2008. Europe remains the region with the greatest growth of world exports, despite the fact that it recorded a reduction from $45.9 \%$ to $41.0 \%$ in 2008 compared to 2007 (Table 1.).World exports are dominated by countries with oil, gas and water resources, developed countries with automotive and electronics industries, advanced telecommunications and information technologies. When we look at the participation of Serbian exports in global exports, structure and geographic diversification, all findings indicate the necessity of fundamental change. The participation of Serbian exports in total world exports is only $0.05 \%$, and its product that has the largest share of world exports, $1.49 \%$, is fruit. Products that are subject to the world's leading exporters are not present among the top 10 products exported from Serbia. An average of 96.22\% of Serbian exports goes to Europe: $13 \%$ of its exports go to Bosnia and Herzegovina, 12\% to Montenegro, $11 \%$ to Italy and $11 \%$ to Germany (Statistics Office of the Republic of Serbia). An unfavorable export structure, inadequate geographical diversification, and faster growth in imports than exports have led to a growing trade deficit.

Joint ventures in the international market are set up by companies that undertake foreign direct investment and companies in the host country that will realize foreign direct investment or government agencies. Active management of investment funds facilitate the entry of foreign companies into markets that would not be possible to enter in other circumstances, such as joint ventures with local companies, which is still the only way to enter the Indian market for international insurers (Skipper and Known, 2007, pp. 430.).

Wholly owned subsidiaries are the way of entering foreign markets that involves the greatest exposure to risk, and is typical for multinational companies, requiring active investment management with managerial skills and experience. Multinational companies began to grow in importance after the Second World War, which was one of the initial impulses for the development of international relations, trade and insurance against political risks.

\section{Attempt to define and analyze the characteristics of political risk}

Political risk means any activity of the state resulting in the reduction of companies' value and capital. Some authors go even further, including political risk activities related to the distinction between domestic and foreign companies, or favoring one or the other, as well as any action of state institutions that produces a threat that may affect the reduction of capital inflows from abroad. Political risk is emerging as a result of government activity and should not be identified with the risk of terrorism, kidnapping or abduction. However, in order to avoid defining it too broadly, political risk generally refers to the damaging activities of the state in the country that implements certain projects. Also, we can distinguish between macro and micro level effects of political risk. The macro level has equal impact on all actors present in a given market, while the micro impact is related to a particular company or industry segments. Political risk is also a very important hidden transaction cost that affects 


\begin{tabular}{lll}
\hline & \multicolumn{1}{c}{ Government risk } & \multicolumn{1}{c}{ Instability risk } \\
\hline \multirow{2}{*}{ Company-specific risk } & - discriminatory regulations & - sabotage \\
& - expropriation of assets & - kidnappings \\
& - breach of contract & - boycotting companies \\
\hline \multirow{3}{*}{ Country-specific risks } & - mass nationalization & - regulatory changes \\
& - currency inconvertibility & - protests and demonstrations \\
\end{tabular}

Source: Wagner, 2000

Table 2: Key factors of impact on business operations in foreign markets

the reduction of international trade (Moser, Nestmann and Wedow, 2006).

According to experts at IRMIs, it is necessary to differentiate between two things concerning the definition of political risk (Wagner, 2000). The first distinction that must be made by the company refers to the definition of the company-specific political risks and country-specific political risks. The second differentiation refers to the types of risk: government risk and risk of instability. The company-specific risk of the country is under the influence of country risk and the risk of instability, which includes discriminatory regulations, the risk of expropriation of assets and breach of contract, sabotage, kidnappings, and the boycotting of companies not under the influence of the state. The degree of country risk is also defined by factors arising from the impact of the state or the risk of instability. This degree is determined by the dangers of mass nationalization, regulatory changes or risk of currency inconvertibility, which are influenced by government, to hazards such as mass workers' strikes, protests, demonstrations and civil wars that are factors of the overall impact (Table 2).

The nature of political risk basically distinguishes between categories of investors (direct or portfolio investors) because their exposure to political risks vary. In general, portfolio investors are indirectly affected by certain political changes, such as, for example, a sudden change in interest rates, while the consequences of political risk for direct investors are much deeper and more radical. The gradation of activities ranges from the lowest ones, which have more of a psychological effect on the management of the company and cause some degree of discomfort and produce relatively little damage, to those that have serious consequences, such as expropriation or confiscation of a company's property. Foreign firms may encounter many difficulties in selling goods or services in certain markets, unlike domestic firms. This is indicated by the fact that the countries of Latin America had a special relationship with companies from the United States, representing a "special service" for rich and powerful U.S. companies. Thus, in Latin American countries after changes in the political scene and the arrival to power of politicians who did not nurture friendly relations with the U.S. administration, had leaders well-known for taking away the assets of foreign companies operating in their territory. This was the case in Chile in 1975 and then in Venezuela in 2006 and 2007.

Until 1985, the map of political risk, as the dominant form of political risk, was the confiscation and nationalization of property and assets of foreign companies in newly independent states. One such example is the exiling of the Shah of Iran in 1979, which led to the nationalization of foreign assets and contracts that were concluded with the Iranian government. The 1973 oil embargo and the nationalization of foreign concessions to the oil fields of the Arab countries led to the Yom Kippur War (Wikimedia Foundation Inc.). In this war, the Arab states led by Egypt and Syria attacked Israel, and as a result an oil crisis arose. The OPEC countries sought a way to punish the U.S. for supporting Israel.

Research by the Aon Corporation dealt with the problem of the influence of political risk on the business of 100 companies, with $86 \%$ of companies stating that political risk is a high threat to their business. A third of the surveyed companies felt the effects of currency inconvertibility and repatriation, a quarter of them suffered losses due to an embargo, and $18 \%$ were subject to expropriation (Aon Corporation, 2001).

\section{Insured political risk}

Nationalization, confiscation and expropriation are the most flagrant actions undertaken by some governments against foreign companies. Foreign governments may also reject the contracts of foreign companies and impose non-recognition of currency convertibility. A comparative analysis of agencies that deal with political risk insurances found a high level of agreement on the risks of nonconvertibility of currency, terrorism and contract termination (Table 3), as well as a lack of full consent with the methodology in Serbia. 
Nationalization is a process of forced transitions into state property of large business enterprises of certain industries or the entire industry that had previously been in private hands, at times with compensation, though this is not obligatory. The seized means of production and other immovable assets become a material base for the construction of a totalitarian state and a means of supporting such a system.

Confiscation means the seizure of the assets of a company without compensation from the government. This type of risk refers to the right of the state to take over - to confiscate the assets of a company or individual if it determines that the business or its results achieved by using the property is not in accordance with the law, or has determined that the movable or immovable property was used for unlawful profit acquisition, smuggling, distribution of narcotics and other actions that are contrary to the law.

Expropriation means the forcible seizure of private property in the common interest, which must be interpreted restrictively, with fair compensation linked to the market value of expropriated property (Wikimedia Foundation Inc). Expropriation is carried out for the benefit of the government, and for the realization of public interest, such as the construction of buildings of public importance or the expansion of industrial zones. The first insurance policy against the political risks of expropriation was issued in the United States in 1951( Moran and West, 2005, pp. 12).

Breach of contract (repudiation, rejection, or simple failure to honor the contract): A state may reject the contract or not recognize it because of certain real or fictitious reasons, which are due to the influence of certain factors beyond the control of the company.

Abandonment of the convertibility of currencies: the ability for currency to be exchanged for other currencies when both are recognized in international payments. In order for a currency to be convertible, it must be supported by a stable economy, and the balance of payments may not show greater and longer-term deficits. If a country declares its currency convertible, and these conditions are not fulfilled, the national economy suffers damage, which can lead to a loss of confidence in a given currency and the suspension of its convertibility. Namely, when the Central Bank sets a fixed exchange rate in which there is trade in the foreign exchange market and when at the same time certain restrictions that apply to trade in the foreign exchange market are introduced we say that the currency is non-convertible or does not have full convertibility. It is in the interest of every national economy that its currency is exchangeable for a large number of currencies, in particular for strong and stable currencies (the Euro, U.S. Dollar, Japanese Yen, Swiss franc). For a national economy it is better to have a stable non-convertible currency than a weak convertible one (Business dictionary).

Political instability: the stability of the political environment in a country is one of the key conditions and factors that determine whether foreign investors will invest their capital in an economy. The decentralization of government, simplification and streamlining of the bureaucracy, and the abandonment of political power to local governments by the central government, are just some of the first steps that need to be taken by the state in order to become attractive to foreign investors. One example is the case of China, where foreign companies are faced with risk related to the fact that the local authorities were forced to accept contracts signed by the central government with the companies, and which were not always in the interests of the local authorities. The stability of the political scene, regular elections, normal functioning of parliament, and economic security over the long term will also ensure that the country is ready for the influx of foreign capital and investment.

War is a direct threat and danger to the property and capital of foreign investors and companies. There is division among theorists in defining war in terms of insurance, especially with regard to how it relates to insurance against political risks. The generally accepted definition of war refers to the attempt to define war as the hostile actions of the military forces of different countries. Some analysts expanded this definition to include any kind of civil war, as well as any kind of armed rebellion. An increasing number of insurance companies have tended to seek to exclude insurance related to the protection of the local, national character of everyday conflict, including civil riots or rebellions on a small scale. It is precisely here that the potential problem for insurance companies lies, which relates to the definition of war, armed rebellion or civil unrest. The question is when civil rebellion turns into a civil war. If the insurance company successfully defines the difference and the moment when revolt grows into a serious conflict, then it can include in its portfolio insurance of this type of political risk, and the company investor can, accepting this type of insurance, calmly and safely plan their strategy relating to their performance in foreign markets. 


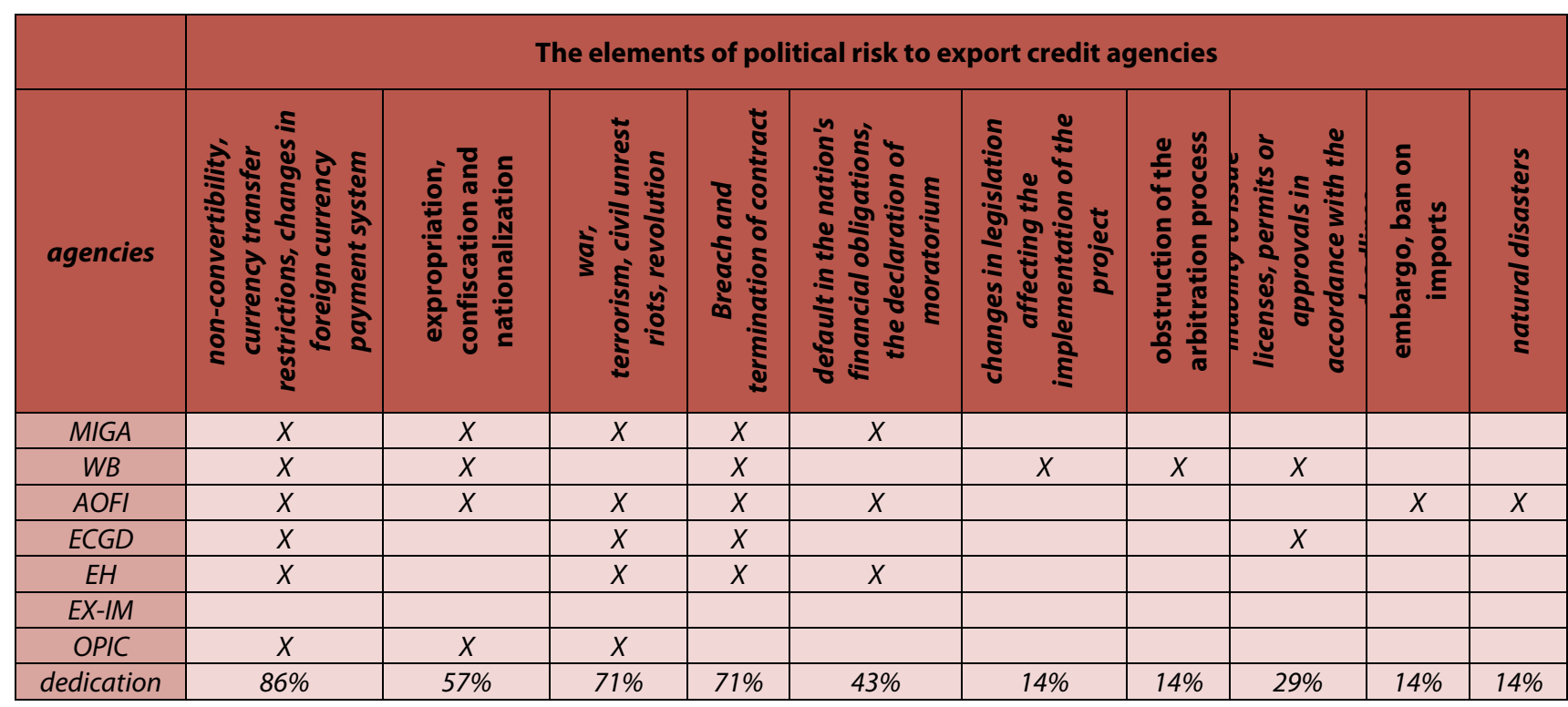

Source: export credit agencies

Table 3: The elements of political risk to export credit agencies

Unpredictable regulatory environment: any company doing business in foreign markets is exposed to the potential risk of discrimination (a distinction made between domestic and foreign investors) coming from the state or its institutions. The forms through which unfairness and inconsistency are manifested are various monetary claims (payment of guaranteed deposits by foreign companies in an amount higher than prescribed), different tax treatments, restrictions in access to resources, sources, their components and distribution. This problem can be resolved to mutual satisfaction and interest if a procurement contract is negotiated between the government and companies. With this contract the company is protected from the discriminatory approach of the country so it can perform equally as well as domestic investors.

The political risks in the Agency for Export Insurance and Financing in Serbia are part of the non-commercial risks. Non-commercial risks include cases where claims cannot be recovered from foreign partners for the following reasons: 1) failure to pay the debt within six months of the agreed maturity date, if the debtor is country, a national organization or person guaranteed by the state; 2 ) political events in the country of the debtor or war in the country of the nationality of the debtor, 3) moratorium of payments, the inability of the debtor country's currency conversion into convertible currency or prohibition of transfer, until the end of this prohibition, 4) the prohibition of imports of goods or services from a state or national organization as a customer or service user; 5) unilateral termination of the contract from a state or national organization as a customer or service user, except with regard to unilateral termination due to breach of customs and health regulations of the importing state or country of the service users; 6 ) seizure, damage, destruction or suspension of goods made by the state or its institutions, from the moment of the transfer of goods across the border to the arrival of the foreign debtor and 7) natural disasters. Under non-commercial risks are considered events that cause damage to domestic entities in connection with assets invested in the company, namely: 1) nationalization, expropriation or other similar measures of the state, 2) the inability to dispose of any assets of at least 12 months due to other measures taken by the state in which the investment was made, 3 ) destruction of or damage to property due to war events in the state in which the property investment is made, or political events in that country (Law on the Export Credit and Insurance of the Republic of Serbia, SI. Gazette no. 61/2005). The risk of natural disaster that stands out is not a typical political risk and the risks of nationalization and expropriation are applied only to property damage.

\section{Managing of political risks - determination and identification of political risks}

Prevention, control and management of loss that occurs as a result of unfavorable political events compels companies operating in international markets to identify and establish sources of potential political risks, as well as 
their level of exposure, in order to create a successful strategy. Entering foreign markets requires each company to have a clearly defined strategy and tactics: whether to "fit" into the local economy or to keep the level of dependency on the local economy to a minimum (Punnett, Ricks and Mendenhall, 1995 pp. 58).

If the company decides to open their branches in a foreign country it is necessary to study its laws, regulations, the elements of its political and tax system and to do an analysis of interstate relations between the countries of origin and the country in which it is planning the realization of its investments. A study of a potential host country includes the study of its history, government, law, demography (including ethnicity and religious affiliation), and its economic and financial market structure. Companies can use publicly published data and information provided by the state and its agencies, from global financial institutions, or its reliable, private sources. The World Trade Organization obtains information relating to trade policy directly from its member countries. The U.S. Central Intelligence Agency periodically publishes the World Factbook (Publication $\mathrm{CIA}$ ), which contains the national, demographic and economic statistics of each country. Also, embassies and consulates in foreign countries send reports to their governments through ministries of foreign affairs. Information related to local authorities, counties or regions is more difficult to obtain because it is collected and published more rarely. This is especially important because amid the process of the decentralization of government a growing amount of political power and responsibility is transferred to local administration. Further growth and development of local communities depends solely on the ability and willingness of local management and the entrepreneurial spirit that manifests itself in the given environment. There are many regions in the world that offer such benefits: economic zones in China, the Maquiladora in Mexico, the area of Labuan in Malaysia, the Customs Free Zone in Dubai. Serbia has also joined this global trend thanks to the ability of local management - Indjija, Zrenjanin and Pećinci.

\section{Measurement and control of political risk}

The aim of measuring political risk is to estimate the negative impact of elements of political risk, i.e. a probability assessment of states taking actions that would be detrimental to the interests of the company that operates in their market. One of the most difficult tasks in assessing political risk is to predict the duration of the negative impact.

\subsection{Political Risk Services - PRS}

Since 1979 when it was founded, the Agency has been recognized worldwide as an original system for measuring and quantifying risks through two subsystems: 1) PRS (Political Risk Services), and 2) ICRG (International Country Risk Guide). The final product of this Agency is the study of country risk. The components of the political risk assessment methodology for PRS include:

A. Government stability: analysis of government unity, legality and public support. Each component is evaluated by a score of $0-4$, with a maximum final score of 12. In 2008, the government of Serbia received 8 points, as a consequence of government cohesion and the establishment of legislative power, but with the divided support of the people. From all of the countries included in the research the German government had the highest number of points (10), which is primarily the result of high cohesion and the legislative power of the government, with a public support subcomponent (1.5) characterized by greater risk when compared to that for the government of Serbia (2.0).

B. Socio-economic conditions include the analysis of unemployment, consumer confidence and poverty. The same method of scoring Serbia was evaluated with 2.5 points, which represents a high risk. Risk is the result of high unemployment (0 points) which in 2008 was $14.7 \%$ and in 2010 was 20\% (Statistics Office of the Republic of Serbia, 2009, unemployment rate), poverty (0.5 points) and consumer confidence. Socio-economic conditions with the lowest risk were typical for the UK (8.5), Germany (8.0) and the USA (8.0).

C. Investment profile and investment: Sustainability of the agreement, repatriation of profit, as well as delay in payment are analyzed (max 12 points). Serbia was assessed with the lowest score in relation to all of the observed countries (7.5) which is attributed to delays in payment and contract enforcement capabilities. The investment profiles of the United Kingdom, Germany and the United States were rated as very low risk. 


\begin{tabular}{cllc} 
number & & & \multicolumn{1}{c}{ components of political risk } \\
\hline 1. & A & government stability & 12 \\
2. & B & socio-economic conditions & 12 \\
3. & C & investment profile and investment & 12 \\
4. & D & internal conflicts & 12 \\
5. & E & external conflicts & 12 \\
6. & F & corruption & 6 \\
7. & G & the influence of the military in politics & 6 \\
8. & H & religious tensions & 6 \\
9. & $\mathrm{I}$ & constitution and laws & 6 \\
10. & $\mathrm{~J}$ & ethnic tensions & 6 \\
11. & $\mathrm{~K}$ & democratic accountability & 6 \\
12. & $\mathrm{~L}$ & quality of bureaucracy and administration & 4 \\
\hline$\Sigma$ & & & max 100 \\
\hline
\end{tabular}

Source: International Country Risk Guide ICRG

Table 4: Components of political risk assessment methodology for PRS

D. Internal conflicts. Analysis of this component includes assessment of civil war (danger of coup), terrorism and civil unrest (max 12 points).

E. External conflict includes analysis of the actions of the government, which extend from non-violent external pressure (diplomatic pressure, withholding aid, trade restrictions and sanctions) to violent external pressure such as cross-border wars. Assessment of this component includes war, border conflicts and external pressures (max 12 points). Serbia is characterized by a high risk of international conflict in the context of foreign pressure (1.5 points), and also had the biggest risks among all of the observed countries.

F. Corruption within the political system is a major threat to foreign investment because it distorts the economic and business environment, reduces credibility and confidence in government and contributes to the instability of the entire system. The most common form of corruption, which comes directly from the company, is financial corruption in the form of specific requests for payments and offering bribes, which are related to obtaining import and export licenses and to reducing tax liabilities. According to the methodology of the PRS Group, favoring certain companies, the secret funding of political parties and the creation of suspected links between politics and business is strictly prohibited. There is a maximum of 6 points in this grade. It was estimated that corruption in Serbia (2) destroys the economic and financial environment and concerns bribes in order to obtain permits, licenses and protection.

G. The influence of the military in politics. Attempting to create a civil society, which means creating a society without the influence of the military, is one of the fundamental pillars of modern democracy. In countries where political, civil, and military unrest are common, the army guarantees peace and order. In some countries, the threat of military takeover of the government by force is a high risk, especially if there are signs that the government cannot function effectively, which is an indication that the country has an uncertain environment for foreign investors and companies.

H. Religious tensions can come from the domination of society and/or management of a religious community that seeks to replace civil law with religious law and exclude other religions from political and/or social processes, reflecting an effort by a religious community to become dominant and influential in official government policy, as well as to express their own identity in a way that constitutes a form of domination over other religious communities.

I. The constitution and laws are evaluated separately, and each sub-component consists of 0-3 points. Constitution is estimated by the strength and impartiality of the legal framework, while the law as a sub-component involves an assessment of compliance with the law (max 6 points)

J. Ethnic tensions include assessments of the degree of tension in the country and whether they are attributable to racial, ethnic and linguistic or other ethnic divisions. A lower rating is present in countries where racial tensions and nationalism are expressed, because the conflicting ethnic groups are intolerant.

K. The democratic stability of a government is conditioned by the support that each government 


\begin{tabular}{|c|c|c|c|c|c|c|c|c|c|c|c|c|c|}
\hline \multirow{2}{*}{ country } & \multicolumn{12}{|c|}{ Components of political risk by label in accordance with Table 4.} & \multirow[b]{2}{*}{ 07/08 } \\
\hline & A & B & C & D & E & $\mathbf{F}$ & G & $\mathrm{H}$ & I & J & K & $\mathbf{L}$ & \\
\hline Max points & (12) & (12) & (12) & (12) & $(12)$ & (6) & (6) & (6) & (6) & (6) & (6) & (4) & $(100)$ \\
\hline Serbia & 8,0 & 2,5 & 7,5 & 9,0 & 7,5 & 2,0 & 4,0 & 5,0 & 3,5 & 3,0 & 5,5 & 2,0 & 59,5 \\
\hline UK & 7,5 & 8,5 & 12,0 & 9,5 & 7,0 & 4,0 & 6,0 & 6,0 & 5,5 & 4,0 & 6,0 & 4,0 & 80,0 \\
\hline US & 7,5 & 8,0 & 12,0 & 10,5 & 9,5 & 4,0 & 4,0 & 5,5 & 5,0 & 5,0 & 6,0 & 4,0 & 81,0 \\
\hline Germany & 10,0 & 8,0 & 12,0 & 11,0 & 10,5 & 5,0 & 6,0 & 5,0 & 5,0 & 4,0 & 6,0 & 4,0 & 86,5 \\
\hline
\end{tabular}

Source: "PRS" and the Coplin-O'Leary System ${ }^{\mathrm{TM}}$, International Country Risk Guide ICRG

Table 5: Political risk rating 07/08

\begin{tabular}{rrrrrrl}
\hline \multicolumn{7}{c}{ political risk rating } \\
\hline 0,00 & $\%$ & - & 49,90 & $\%$ & very high risk \\
50,00 & $\%$ & - & 59,90 & $\%$ & high risk \\
60,00 & $\%$ & - & 69,90 & $\%$ & medium risk \\
70,00 & $\%$ & - & 79,90 & $\%$ & low risk \\
80,00 & $\%$ & - & 100,00 & $\%$ & very low risk \\
\hline
\end{tabular}

Source: "PRS" and the Coplin-O'Leary System ${ }^{\mathrm{TM}}$, International Country Risk Guide ICRG

Table 6: Political risk rating scale

\section{Very high risk \\ high risk \\ medium risk \\ low risk \\ very low risk}

Source: International Country Risk Guide ICRG (WC - Worst Case and BC - Best Case)

Table 7: Categories of the combined rating of political, financial and economic risk

\begin{abstract}
00,0 to 49,9 points
50,0 to 59,9 points

60,0 to 69,9 points

70,0 to 79,9 points

80,0 to 100,0 points
\end{abstract}

has in parliament, as well as whether confirmation of support is received through elections. Under this component, attention is especially given to the following factors: the existence of free and fair elections for legislative and executive power, the active presence of more than one party in power and the sustainability of the opposition and the cooperation, stability and smooth functioning of the three pillars of government - the legislative, executive and judicial.

L. The quality of bureaucracy and administration. High marks are given to countries where bureaucracy has strength and expertise without drastic submission to political changes. In countries with high marks, bureaucracy tends to be somewhat autonomous from political pressure and has an established mechanism for recruitment and training. Countries that lack a strong, high quality and efficient bureaucracy receive low points because any change in the government implies changes in the bureaucracy. Serbia has low risk in terms of bureaucracy (2 points).

The sum of the values of individual components of political risk in relation to the maximum amount (100) defines the political risk rating, i.e. the level of risk (Table 6.). In July, 2008 Serbia had a high level of political risk
(59.50\%) and other observed countries had very low risk. The components with very high levels of risk are socioeconomic conditions and corruption, while there is very low risk in Serbia in terms of democratic stability.

The methodology for measuring the combined current rating and the prediction of the rating for 1 year and 5 years includes the prediction of the best and the worst variants in the period of the prediction. The combined rating of risk includes the political (PR), financial (FR) and economic (ER) risks, whereas political risk contributes $50 \%$ and the remaining two $25 \%$. The combined rating (CPFER) for country $\mathrm{X}$ is calculated by using the following formula: CPFER (for country $X$ ) $=0,5^{*}$ (PR + FR + ER).

The combined rating of Serbia in 2007 was 65.8, which falls within medium risk, and 61.8 in 2008, which is also medium risk. The combined rating in 2008 is the result of the high political risk (59.5), medium economic (30.0) and financial risk (34.0). The best variant of the combined rating for the period of up to one year does not lead to essential changes in the rating of Serbia, as the risk level remains medium. For a period of up to 5 years in the context of the best variant, the changes are significant for Serbia, as the combined rating is 73.5 and the country's risk is low. The worst variant of the prediction for the period of up to 5 years puts Serbia in the group of 


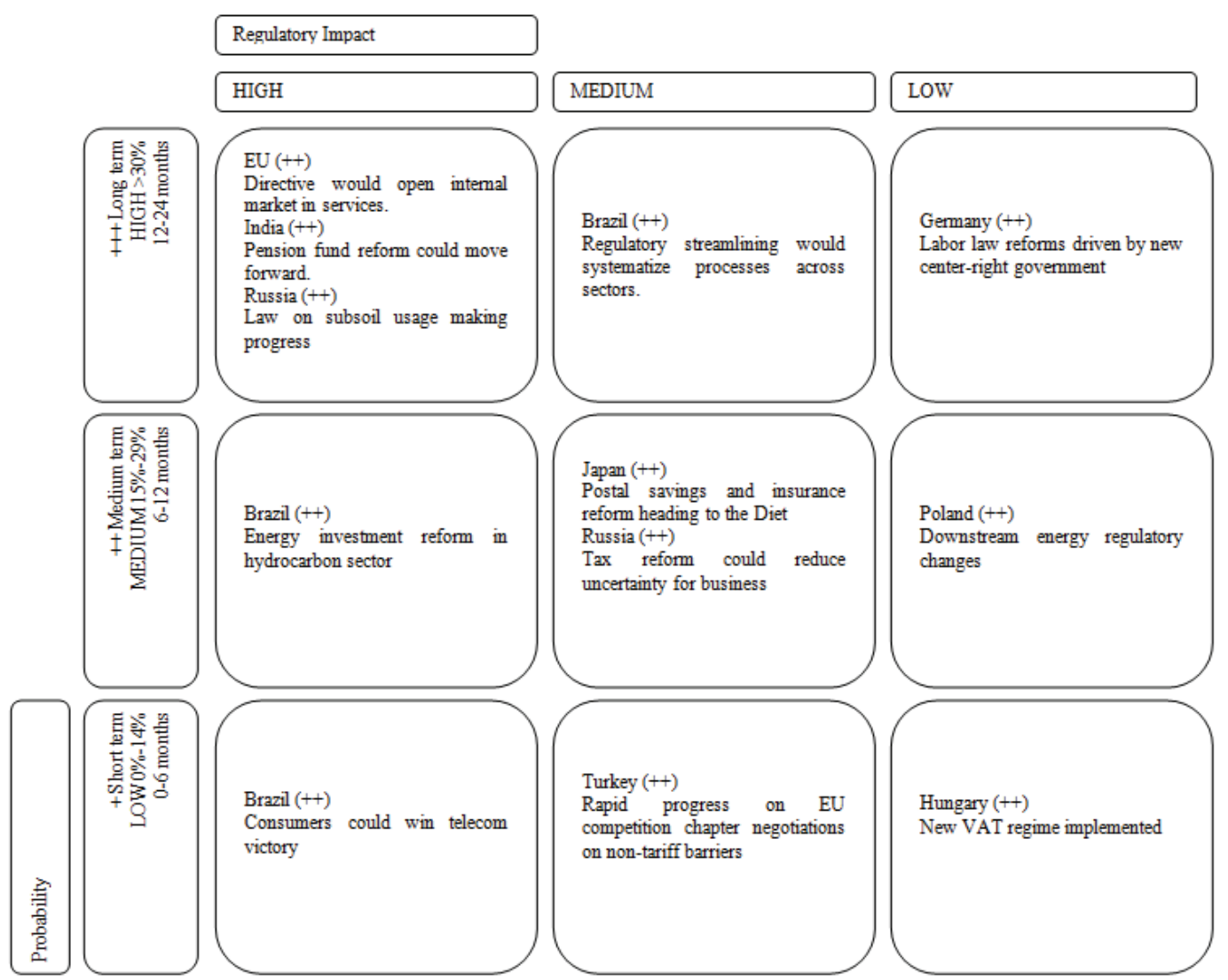

Source: Integrating Political Risk into Enterprise Risk Management, 2006, Pricewaterhouse Coopers International Limited i Eurasia Group Table 8: The unique methodology of PwC and EG

countries with a very high risk. A very low combined rating for 2008 was held only by Germany (89.3). The highest value of the combined rating is 100.0 and represents very low risk, and the lowest value of the combined rating is 00.0 and represents very high risk (Table 7).

\subsection{PricewaterhouseCoopers International Limited and Eurasia Group - unique methodologies}

Eurasia Group has defined a unique methodology for financiers and corporate leaders that represents a synthesis of theories of political science and financial expertise. Knowledge of the political circumstances of each individual country represents the ideal environment for the anticipation of the future and making the right management decisions. Planning operations in a foreign market based on knowledge of its political circumstances and figures, and on awareness of the importance of the ministries and departments that dictate its macroeconomic policy, is certainly a competitive advantage for decision makers. Eurasia Group brings together experts from all the countries on whose knowledge a comparative analysis of a country risk is based and carried out.

The unique methodology (Table 8) is based on the impact of regulations, the probability of regulatory changes and the time dimension. The regulatory influence may be high, medium or low. The probability of the occurrence of regulatory changes may be low (up to $14 \%$ ), medium (from $15 \%$ to $29 \%$ ), or high (over $30 \%$ ). The probability of the occurrence of regulatory changes is seen through three dimensions: the short, medium and long terms. For example, the introduction of the new VAT regime in Hungary has a low regulatory impact, with the medium probability of the occurrence of regulatory changes (from $15 \%$ to $29 \%$ ) in the next 6 to 12 months.

\subsection{The Methodology of the Organization for Economic Cooperation and Development}

The OECD methodology for determining credit and political risk is important from the point of application of a "Gentlemen's Agreement" and determining the minimum premium rates and the cost of capital. The starting point for the formation of the "Agreement," i.e. 


\begin{tabular}{lcccccc}
\hline year & Serbia & Bosnia and Herzegovina & Croatia & UK & Germany \\
\hline 1999. & 7 & 7 & 5 & 0 & 0 & 0 \\
2004. & 7 & 7 & 4 & 0 & 0 & 0 \\
2009. & 7 & 7 & 5 & 0 & 0 & 0 \\
2010. & 6 & 7 & 5 & 0 & 0 & 0 \\
\hline
\end{tabular}

Source: Country Risk Classifications of the Participants to the Arrangement on Officially Supported Export Credits $1999-2010$

Table 9: Country risk OECD

for establishing rules for the functioning of the official export credit agency, is striving among exporters to compete in terms of price and quality, and not on payment.

The OECD methodology distinguishes between two models: 1) the Country Risk Assessment Model (CRAM) is based on the assessment of quantitative indicators of country credit risk, based on experience in the settlement of obligations, and the financial and economic situation of the country; 2) Qualitative customized results factors, which are not taken into account (the political situation in the country). Country risk is classified into 8 categories of risk from 0 to 7 (Table 9). Serbia for the past 10 years has always had a rating of 7 , i.e., among very high risk countries, and in 2010 the rating improved for the first time after 10 years to a 6 . Rating improvement will affect the insurance premium reduction for countries that do business in Serbia, as well as a reduction in interest rates. According to research by the Government Council for the European Integration of Serbia it was determined that companies that are operating with Serbia will pay lower prices for export credit insurance and that interest rates could be lowered by about $0.2 \%$ (Government of Serbia).

From the banking sector viewpoint, country risk is gaining importance in the context of the risk management of international public and private loans. The implementation of international loans triggered the following risks: the risk of debtor countries, nonconvertibility risk, risks of delays and the inability to collect receivables, and the risks of various rights and legal regulations. Country risk for each bank determines the limit that defines the maximum possible exposure of banks to customers from that country. The maximum exposure to risk is the product of bank capital, a category rating of the country and the macroeconomic indicators of the country. When calculating the minimum active interest rate that should cover the cost of capital and product, banks start from the transfer price of capital, which contains the interest rate margin, the price of country risk and regulatory costs. Price of country risk is exactly proportional to the capital cost and the length of the maturity of the loan. Credit insurance increases the possibility of withdrawing credit from abroad, with a lower political risk meaning a lower interest rate and premium. German insurers (THE GERMAN INSURANCE ASSOCIATION) advocate for the adoption of policy loans by the bank as part of the capital, but it remains unclear whether the credit insurance policy may also apply to political risks or only to commercial ones.

\section{Insurance by international or global agencies}

International or global agencies in the last 20 years have become a factor for stability in terms of providing assistance and guarantees to investors for the markets, whether in their expressed political or other risks.

\subsection{Multilateral Investments Guarantee Agency - MIGA}

In 1988 the World Bank established the Multilateral Investment Guarantee Agency - MIGA - which is engaged in promoting foreign direct investment in countries with emerging markets to improve living standards and reduce poverty. Given that $30 \%$ of foreign direct investment goes to low-risk, high income countries and only $12 \%$ of foreign direct investment goes to highrisk, low-income countries it was necessary to encourage investors to invest in developing countries (Moran and West, 2005, pp. 2). MIGA provides insurance that protects lenders and investors against political risks, and helps developing countries to attract and retain private investment (Multilateral Investment Guarantee Agency, 2009), as well as co-insurance and reinsurance against political risks to MIGA member countries concluded in favor of the private sector. Since its establishment, MIGA has issued guarantees worth 21 billion USD for more than 600 projects in 100 developing countries (Multilateral Investment Guarantee Agency, 2009). MIGA currently has 173 member countries, and has capital of over 1 billion euro. MIGA in its portfolio includes coverage of the following types of risks: expropriation, failure to enforce contracts, war and civil unrest, abandonment of the 
convertibility of currencies (it does not provide for the devaluation of the local national currency of the host country). Insurance services involve a combination of these four types of risk, and cover up to $90 \%$ of investments and up to $95 \%$ of claims, for 15 or 20 years, respectively. MIGA also provides guarantees to local authorities that investors comply with social standards and standards for environmental protection.

Insurance premiums of foreign direct investments from political risks depend on the country risk and project risk. Country risk is the responsibility of the Political Risk Insurance Center, which is a part of MIGA, and a free database on the management of political risks and insurance. Insurance premiums are between $0.45 \%$ and $1.75 \%$ per year. The premium rate of insurance against political risk depends on country risk, insurance and reinsurance capacity, activities that are the subject of insurance, previous experience with claims and losses, the credit worthiness of the insured, the usefulness of the project that is the subject of insurance, the type and number of commercial/political risks, the period of insurance and the factor of negative selection due to increased competition.

\subsection{World Bank insurance program}

The World Bank guarantee is issued only with the counter-guarantee of the government. The World Bank guarantees for the project only if the host government is not able to do so. All insurances that originate from this global financial institution can include some of the following risks (the World Bank):

- Partial risk insurance refers to risk coverage that can originate if the government or one of its agencies does not comply with all of the obligations towards the company or private investor; the World Bank issues a guarantee to the company that is founded for the realization of projects for special purposes, in favor of the private investor. This insurance is suitable for specific types of concessions, i.e., the transfer of construction plants or processes, through the funding of projects under the B.O.T. System and Public Private Partnership (as a form of cooperation between public service and private companies in order to reduce costs and more efficiently use private expertise).

- Partial credit insurance includes protection from all risks related to financing the debt arising from public investment, and insures that the state pay private investors for the work performed; this type of credit insurance is specifically designed with the aim of extending the maturity of the project and improving market conditions.

- Policies based on the guarantee give assurance of the payment on principal and interest on the private market to investors that are buying debt securities issued by the IBRD of the member states and whose property provides qualification for certain projects whose risks are covered by the World Bank.

\section{Insurance by agencies that are wholly or partially state-owned}

Insurances against political risk, particularly from export risks, may come directly from the state, government agencies or from private insurance companies that have the support and assistance of the state.

\subsection{United States}

The U.S. administration provides support for political risks through the following:

- The Export Import Bank was established in 1934 as an American banking corporation that operates as an independent agency of the U.S. government and represents a pillar of the foreign policy of the U.S. administration. As such, this bank is not allowed to provide financial assistance, including insurance to public and private sectors in certain countries that are on a list of restrictions directly determined by the federal government. The Ex-Im Bank, as a part of its portfolio, provides insurance that covers export credit (the risk of bankruptcy, insolvency, credit disability, the risk of uncollectible claims and fraud) and political risk. The Bank has proved very successful in conducting its own policy, which, in its offers includes a combination of credit and political risk. The first variant, the so-called multi-buyer or master policy, provides support and cover for $90 \%$ of the business arrangement, and in some cases, the bank can cover up to $100 \%$ of contract value on a long-term basis. The second variant relates to the coverage of credit and political risk up to $95 \%$ of the value, and in agricultural products up to $98 \%$.

- Overseas Private Corporation for Trade Insurances - the Cooperation Treaty from 1948 gives the possibility for a domestic multinational 
company to have political risk insurance. Agreements on assistance abroad, which came into force in 1969, reallocated a part of portfolio insurance from the state to the newly formed body of the OPIC, which began operations in 1971. Insurance covers the risk of currency inconvertibility, nationalization, expropriation, confiscation of property by other states and political violence in over 250 countries worldwide. Coming into force at the insured event, the OPIC pays compensation for damage to physical assets and for the loss of business income due to the damage of physical assets. OPIC charges a fee for services, operates completely independently and does not create costs to taxpayers.

\subsection{United Kingdom}

The United Kingdom in 1919 established a department for export-credit insurance against political risks, which is state-owned and has been providing insurance against political and credit risks. Its basic principles are:

- An export credit insurance policy directed to support lending, and also direct investments; in the case of loss caused by exporting the goods and services in developed countries it covers up to $95 \%$ of the loss. The insurance covers insolvency and inability to collect receivables, contractual commitments, currency inconvertibility, the disclaimer of contracts by the state, as well as administrative and other restrictions by the state.

- A liability insurance policy focused on insuring any kind of binding obligations of the insured exporters or investors: unfair calls from unusual political events (war, riots, repudiation of contracts) and that are related to the advanced payment of guarantees, the distribution of priority shares, and the guarantee account; it covers $100 \%$ of loss.

- Tenders for contract offers and amendments to deposited bills cover the risk of the unfavorable exchange of credit annuities, which are required to be paid by the company, and whose payment currency is issued in the currency of the country in which the investment projects are implemented.

The department in its business operations uses an agreement on guidelines for export credits that is supported by official export agencies and which limits financing of subsidized trade through the definition of the limits (interest rate, maturity, prepayment and repayment mode), exchange rates and information exchange as part of business practice. Determining the minimum premium rate for the country risk is also defined by the Knaepen Package agreement created in 1999 and that allows for the calculation of premiums that should cover the risk of failure to collect export credits, and to cover long term operating costs and loss in case of credit risk. The coefficient, which refers to the category of country credit risk, is determined by the elements of political risk: a general declaration of the moratorium of loan repayment, the political events that prevent or cause a delay in the settlement of loans, the legal provisions that define the convertibility of currencies, war, expropriation, revolution, insurrection and civil unrest.

\subsection{Germany}

EULER HERMES (EH) is the best export credit agency and was established in 1917. 68\% is owned by Allianz France, $28 \%$ by Germany and $4 \%$ by EH. EH has a $49 \%$ equity ownership in OeKB Beteiligungs-und Management $A G$, whose insurance of credits includes coverage of political risks. Political risks are risks related to legislative and administrative measures, war, insurrection or revolution, which prevent the payment of secured claims; transfer and conversion risk due to inability to convert or transfer the local currency of the customer due to a moratorium of payment; loss of goods due to political events; loss due to the failure to execute contractual obligations.

EH provides a service of credit insurance directly to the exporter or the bank of the exporter, and insurance through a link with the state of Germany. The Research Center of Deutsche Bank analyzed the dependence of political risk of German exports and insurance on projects from 130 countries in the period from 1991 until 2003, as well as the economic effects of political risk insurance. The main results suggest that political risk is an important obstacle to exports, and political risk in the importing country has a significant negative impact on German exports while export credit insurance has a positive and significant impact on exports. With the aim of determining the interdependence of the insurance of export credit and political risk, the gravity model was used as an econometric ex-post technique with the assumption that trade between Germany and other countries depends on the economic size and all types of 


\begin{tabular}{lllc}
\hline & Insurer & country & established \\
\hline 1 & ATRADIUS & Netherlands & 1953 \\
\hline 2 & EH GERMANY & Germany & 1953 \\
\hline 3 & FCIA & USA & 1963 \\
\hline 4 & PWC & Germany & 1974 \\
\hline
\end{tabular}

Source: Multilateral Investment Guarantee Agency, 2009, pp. 90-91

Table 10: Private political risk insurers

transaction costs, the transportation costs, information costs and hidden costs such as political risk. Countries with less stable government, with a higher probability of internal and external conflicts and higher levels of corruption have a negative impact on German exporters, i.e. a $1 \%$ increase in the political risk index leads to a reduction in exports of $0.1 \%$ in the short term and $0.65 \%$ in the long term. (Moser, Nestmann and Wedow, 2006.)

\subsection{Serbia}

Political risk insurance in Serbia is the responsibility of the Agency for Export Credit and Insurance (AOFI). The AOFI was formed in order to reduce the country's balance of payments deficit, increase employment, provide support to domestic legal entities and entrepreneurs, and form the institutional framework to support the development of national exports and export economy and to improve the structure and competitiveness of exports and economic development relations with foreign countries. The activity of the Agency is defined by the Law relating to the insurance of export transactions and overseas investments, financing, co-financing and refinancing of export transactions, financing of export preparation and investments, insurance of export preparation, financing a foreign buyer regarding the export of a domestic legal entity, insurance of domestic banks and other financial institutions from noncommercial risks associated with guarantees for export transactions, issuing guarantees and providing services related to export financing and insurance and investment from non-commercial and commercial risks. The insurance premium charged by the agency depends on the risk of the country of export (according to OECD classification), the volume of exports to be insured, payment terms for the foreign buyer, foreign buyer creditworthiness and the experience of exporters in relation to the payment of claims abroad. The state is responsible for the obligations of the Agency with respect to insurance of the exporter for non-commercial risks to the amount that is determined by the law governing the annual budget of Serbia. European export credit agencies stand out in their businesses in that even though they are state property, the agency must not burden the citizens, and therefore the state budget.

\section{Insurance from private insurance companies}

The global growth of international trade and investment has led to the occurrence of new private insurers that have entered the market of political risk insurance. In 1974 the Financial Times declared that "the development of private political risk insurance is a consequence of the inability of investors to get the same from the official agency for all types of investment and for all countries". The private sector is dominant in shortterm insurance.

The first private credit insurer of political risks is ATRADIUS, which was originally founded with the aim to work together with the Dutch government to provide export credit insurance service to Dutch companies. Political risk is defined as the risk of the government of the customer's country that prevents the fulfillment of transactions or the risk of failure to meet obligations or risks that are beyond the individual responsibility of the costumer. In 2008 portfolios saw their largest growth in revenues by products in areas demanding political risk insurance, around $27.3 \%$ (ATRADIUS, 2008, pp. 5).

The U.S. private market of political risk insurance began to develop in the early '70s of the last century. The largest company engaged in political risk insurance is the American International Group (AIG), which has been providing this kind of risk since 1974.

In Serbia there is no private insurance company offering policies against political risk.

\section{Conclusion}

There is consensus that political risk is an important part of country risk and that the state is the source of these political risks. The majority of the export credit agencies observed (more than $71 \%$ ) have decided that the basic elements of political risk (Table 3 ) include: nonconvertibility of currency, expropriation, confiscation and nationalization, terrorism and breach of contract. AOFI 


\begin{tabular}{|c|c|c|c|c|c|}
\hline Agency & Established & $\begin{array}{l}\text { premium } \\
\text { insurance }\end{array}$ & $\begin{array}{l}\text { period of insurance } \\
\text { in years }\end{array}$ & Cover in \% & $\begin{array}{l}\text { Micro and } \\
\text { SME } \\
\text { companies }\end{array}$ \\
\hline MIGA & 1985. & $0,45 \%-1,75 \%$ & $15-20$ & $90 \% / 95 \%$ & yes \\
\hline WB & 1944. & $0,15 \%-0,75 \%$ & $\mathrm{n} / \mathrm{a}$ & $100 \%$ & yes \\
\hline AOFI & 2005. & $\mathrm{n} / \mathrm{a}$ & $\mathrm{n} / \mathrm{a}$ & $\mathrm{n} / \mathrm{a}$ & not specified \\
\hline ECGD & 1919. & $\mathrm{n} / \mathrm{a}$ & $2-5-15$ & $75 \% / 85 \% / 95 \% / 100 \%$ & yes \\
\hline $\mathrm{EH}$ & 1917. & $\mathrm{n} / \mathrm{a}$ & $\mathrm{n} / \mathrm{a}$ & $\mathrm{n} / \mathrm{a}$ & yes \\
\hline $\begin{array}{l}\text { Ex-Im } \\
\text { Bank }\end{array}$ & 1934. & $\mathrm{n} / \mathrm{a}$ & $\mathrm{n} / \mathrm{a}$ & $95 \% / 100 \%$ & yes \\
\hline OPIC & 1971. & $\mathrm{n} / \mathrm{a}$ & $\mathrm{n} / \mathrm{a}$ & $75 \% / 90 \% / 100 \% / 270 \%$ & yes \\
\hline
\end{tabular}

Source: Export Credit Agencies

Table 11: Overview of the basic elements of agencies that deal with political risk insurance

opted for the above elements of political risk, provided that the above risks in practice do not apply to export credit insurance (because the product does not exist as such), which is not observed with other agencies. Managing political risk, regardless of ownership (transnational, national, private) is generally the responsibility of export credit agencies. The AOFI has not developed a transparent environmental policy and policy against corruption, money laundering and bribery.

$86 \%$ of the observed export credit agencies chose to provide services to micro, small and medium enterprises, while the AOFI did not specify the orientation of the target group of micro, small and medium enterprises, where this should be done as the total number of registered enterprises in Serbia in 2008. 99\% were referred to as micro, small and medium enterprises that employ $59 \%$ of the employees, whose turnover represents $61 \%$ of the total turnover in Serbia and $53 \%$ of the gross value added. Also, SMEs contribute $50 \%$ of exports and $51 \%$ of all investments (www.economy.rs).

Given that political risk is a part of country risk, it proportionally impacts on price of capital and the rates of insurance premiums. Banks and export credit agencies have come to the same conclusion, namely that country risk is the only "place" where it is possible to carry out a planned reduction in interest rates and insurance premiums. The insurance premium for the observed export credit agencies ranged from $0.15 \%$ to $1.75 \%$ (Table 11).

Export credit agencies have agreed to export credit insurance in the short, medium and long term, provided that there is no unanimity over the meaning of the terms. Short-term insurance is up to 1 year and up to 2 years of insurance for the Belgian Agency for Credit Insurance. The scale of insurance coverage against political risks ranges from $75 \%$ to $270 \%$, while the AOFI has not defined its coverage.
Given the unavailability of an adequate database and the lack of standards it is impossible at the national level to determine the effect of economic management and political risk insurance and the impact on macroeconomic stability in the foreign trade multiplier. Research by the German export credit agency has confirmed the positive multiplication of insurance and political risk.

If export insurance agencies have adequate levels of capital, high-quality products, services that follow global trends, expert staff and competitive premiums, as a consequence of the absence of country risk and political risk, your health insurance as a measure of political risk management directly affects the growth and development economics. $[$.

\section{References}

Aon Corporation, 2001. Aon Survey: Majority of Fortune 1000 Firms Feels More Vulnerable to Political Risks than Other Types of Losses, http:// www.aon.com (accessed October 10, 2010).

Atradius, 2008. Annual report 2008, Amsterdam, http://global.atradius.com/corporate/ about us/annualreportspage.html (accessed April 26, 2009).

Friedman, M. and Friedman, R. 1996. Free to Choose, Novi Sad: Global book.

Grath, A. 2008. The handbook of International Trade and Finance, London: Kogan Page Limited.

Moran, H. T. and West, T. G. 2005. International Political Risk Management Looking to the Future, Washington D.C.: The World Bank.

Moser, C., Nestmann, T. and Wedow, M. 2006. Political risk and Export Promotion: Evidence from Germany, Deutsche Bundesbank, University of Mainz: Deutsche Bank Research Frankfurt am Main Germany.

Multilateral Investment Guarantee Agency, 2009. World Investment and Political Risk 2009 http://www.miga.org/news/index_sv.cfm?aid=2486, Washington D.C.: The World Bank MIGA (accessed December 06, 2009)

Multilateral Investment Guarantee Agency, 2009. http://www.miga.org/projects/ index_sv.cfm, Washington D.C.: The World Bank MIGA (accessed December 06, 2009)

Ostojic, S. 2009. Fundamentals of Monetary Economics, Belgrade: Data Status. 
Ostojic, S. 2007. Insurance and Risk Management, Belgrade: Data Status.

Poslovni rečnik,

http://www.beogradnet.com/index.php?page=brecnik\&cat

PricewaterhouseCoopers International Limited and Eurasia Group, 2006. Integrating Political Risk Into Enterprise Risk Management, http://www.pwc.com and http://www.eurasiagroup.net (accessed May 27, 2009).

PRS and the Coplin-O'Leary System ${ }^{\mathrm{TM}}$, International Country Risk Guide ICRG, East Syracuse NY USA, http://www.prsgroup.com (accessed April 04, 2010).

Punnett, B. J., Ricks, D. A. and Mendenhall, M. E. 1995. Global management, Cambridge: Blackwell Publishing.

Skipper, H. D. and Known, W. J. 2007. Risk Management and Insurance: Perspectives in Global Economy, Oxford, United Kingdom: Blackwell Publishing,

The World Bank, World Bank Guarantee Program, http://web.worldbank.org/external/default

Wagner, D. 2000, Defining Political Risk, International Risk Management Institute, http://www.irmi.com/expert/articles/2000/wagner10.aspx.

Wikimedia Foundation Inc., http://sr.wikipedia.org/sr-eleksproprijacija.

Wikimedia Foundation Inc., Yom Kippur War, http://en.wikipedia.org/wiki/Yom_Kippur_War

Willkin, S. and Minor, J. 2001. Managing Today's Political Risks, The Risk Management Letter no 22.

World Factbook, 2010, CIA Publication, https://www.cia.gov/library/publications/the-world-factbook/ (accessed April 24, 2010)

WTO Publications, 2008. International Trade Statistics, Geneva: WTO Secretariat.

http://www.wto.org/english/res_e/statis_e/its2008_e/its08_toc_e.htm

\section{Abbreviations}

MIGA Multilateral Investments Guarantee Agency

WB World Bank insurance program

AOFI Export Credit and Insurance Agency of the Republic

of Serbia

ECGD Export Credits Guarantee Department

EH EULER HERMES

EX-IM Export import bank

OPIC Overseas Private Corporation for Trade Insurances 